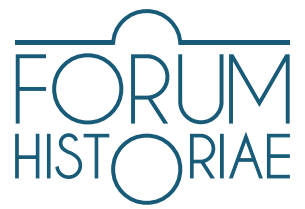

\title{
Czech Sci-fi Fanzines in the Era of Late Socialism and Early Post-socialism
}

\author{
Antonín K. K. Kudláč
}

\begin{abstract}
KUDLÁČ, Antonín K. K.: Czech Sci-fi Fanzines in the Era of Late Socialism and Early Post-socialism. Fanzines have been among the most significant means of communication for the subculture of fans and "users" of the fantastic arts, so-called sci-fi (SF) fandom, since the birth of the genre. This is also the case in Czechoslovak (later Czech and Slovak) fandom, for which fanzines primarily represented the activities of SF clubs. The community of Czechoslovak fans mostly belonged to the "grey zone" of late socialist society, where fandom members were more or less tolerated. After 1989, Czechoslovak SF fandom changed into a more formally organised structure; some of the existing SF fanzines disappeared and others became the basis for professional magazines or publishing houses. However, traditional fanzines connected with SF clubs have continued. Fanzine production has at the same time gradually moved into the sphere of digital publishing (e-zines/webzines). Digitisation of fanzine publishing clearly reflects changes in SF fandom, which has been oscillating between a social alternative to and cooperation with the cultural industry.
\end{abstract}

Keywords: SF fanzines; SF fandom; participatory culture; late socialism; post-socialism

DOI: https://doi.org/10.31577/forhist.2020.14.1.3

$\mathrm{T}$ he publication of unofficial literature in the extensive cultural-geographical area of the so-called "Eastern Bloc" in the second half of the $20^{\text {th }}$ century has been the subject of much research by historians of contemporary history, literary critics and cultural anthropologists. ${ }^{1}$ There existed an extremely wide range of publication forums, distribution channels, themes and links between the "official" and "unofficial" levels of social communication, which differed across the countries of Central and Eastern Europe. Periodicals connected with the activities of various subcultures, some of them bordering on the illegal, formed a remarkable part of this publishing phenomenon.

The aim of my study will be to outline the basic characteristics of the publication activities of members of the sci-fi (or SF) fandom subculture, both in the period of late socialism as well as in the subsequent years and show both the continuities and discontinuities in this community against the backdrop of socio-cultural changes in Czech society after 1989. I understand subculture to be a social group with its own rules, which may define itself in opposition to the majority of society, but which is not completely isolated, and whose members may also be part

1 At present there is extensive secondary literature on this subject on an international level, much of which focuses on Russia, where the samizdat activities started. The general context for Central-Eastern Europe during the time we are considering in this study has been examined by, e.g. KIND-KOVÁCS, Friederike LABOV, Jessie (eds.) Samizdat, Tamizdat, and Beyond: Transnational Media During and After Socialism. New York : Berghahn Books, 2013. 
of other subcultures; therefore, I tend towards so-called post-subcultural theory. ${ }^{2}$ I will also try to answer these questions: During this period, in what ways did Czech SF fandom change and how did the publication of SF fanzines alter within this framework, particularly under the new economic conditions? To what extent did this subculture resist the regime before 1989, and how much sensitivity have its members shown towards social issues in the post-socialist era?

The period of change between the fall of the communist regime and the gradual social, political and cultural transformation at the turn of the $21^{\text {st }}$ century also led to a significant reassessment of both the means of communication as well as, more generally, the reason for the existence of communities that defined themselves in their own way as "alternative". These changes had hardly any effect on some of these subcultures, while others were hit quite dramatically. In addition, other communities only began to develop within the new climate. As for the publication of fanzines in a Czech context, research today (the great majority being "insider research") is only starting to examine the basic outlines of what happened during this transitional period and the consequences it had for developments to come, ${ }^{3}$ while encountering ambiguously defined basic terms, including definitions of the terms "samizdat", "fanzine" and so on.

\section{SF Fandom}

\section{Czechoslovak SF fandom before 1989}

The establishment in 1969 of the Jules Verne Club (and its rapid demise) was a foretaste of things to come. This club was the first association of lovers of fantastic literature in Czechoslovakia. However, the establishment of a fan club, later called Villoidus, by students of the Mathematics and Physics Faculty at Charles University in Prague at the end of April 1979 is often regarded as the start of Czech SF fandom. ${ }^{4}$ Other similar SF clubs then rapidly appeared, totalling around twenty by the mid-1980s. An important milestone in the development of fandom was the first Czech national con (a meeting of SF fans), which took place in Pardubice on 23 April 1982, and later became known as the Parcon. This was also the venue for the announcement of the results of the Karel Čapek Award for literature, which is still considered the most prestigious national competition in fantastic literature. The publication of amateur magazines - fanzines (see below) - was also part of the activities of SF clubs.

Due to the rapid expansion of fandom activities, a Coordination Commission was set up in March 1983 to link the activities of the individual SF clubs; then shortly

\footnotetext{
2 See: HILLS, Matt. Fan Cultures. London ; New York : Routledge, 2002.

3 The last to summarize this issue during this period was HROCH, Miloš. Zkoušel si někdy hodit mentos do koly? In HROCH, Miloš (ed.) Křičím: „To jsemjá“: Příběhy českého fanzinu od 80. let po současnost. Praha : Page Five, 2017, pp. 25-35. The Czech and Slovak Archive of Subcultures has a purely documentary role, see: http://ziny.info/.

4 KUDLÁČ, Antonín K. K. Anatomie pocitu úžasu: Česká populární fantastika 1990-2012 v kulturním, sociálním a literárním kontextu. Brno : Host, 2016, p. 95.
} 
afterwards Interkom ${ }^{5}$ was established as "a fanzine for communication between SF clubs". 6 The Coordination Commission convened regular "spring", and "autumn" meetings of SF clubs, and the Mlok and Ludvík awards were established to recognise exceptional achievements in fandom and were awarded regularly at Parcon. During the early 1980s, Czechoslovak fandom fully developed into the form of a loose association of fans of fantastic literature which was not centrally administered and which included several local units, its own publication network, literary competitions and special subculture awards. Naturally, this community differed in certain ways from similar associations in the USA and Western Europe.

Until 1989, Czechoslovak SF fandom had relatively few international contacts. Its members generally found out about "Western" fantastic literature through the Polish fans they were in contact with. During the 1980s, some Czech fans occasionally managed to attend international events, such as Eurocon or Worldcon (the first mention of the existence and activities of Czechoslovak fandom was at Eurocon in Ljubljana in 1983), but the local subculture remained at the edges of the international scene. ${ }^{7}$

Another difference was the lack of professional representatives in this subculture, as only a few full-time writers published fantastic literature. Although official publishers (Mladá fronta, Svoboda) brought out short-story anthologies by local writers, they were unable to publish a professional periodical during this period. This relates to the communist regime's attitude towards SF fandom in general although the state-cultural apparatus outwardly supported or tolerated fantastic literature (from 1980 - 1987 there even existed the Commission for Science Fiction Literature within the Union of Czechoslovak Writers), the majority of subcultural activities bordered on "semi-legality", often officially patronised by organisations, such as the Union for Cooperation with the Army (Svaz pro spolupráci s armádou - Svazarm), central organisations of the Socialist Union of Youth (Socialistický svaz mládeže) or trade unions, though more often than not these activities occurred outside of them. ${ }^{8}$

\section{The structure of Czech/Slovak SF fandom after 1989}

With the establishment of a professional organisational basis, fan subculture then had to be described using two terms: Fandom and fandom. These terms describe its two sides, which only partially overlap. The word "fandom" describes the subculture as a whole, whilst "Fandom" is its formally organised "hard core", where a strong position is held by the "dinosaurs" - supporters of fandom who can remember the beginnings of this subculture - i.e. a kind of veteran. Around this core are the so-called "wild fans" - unorganised supporters of the subculture who can

5 RAMPAS, Zdeněk - OLŠA, Jr., Jaroslav. Interkom. In PŘIBÁŇ, Michal (ed.) Český literární samizdat 1949_ 1989:Edice, časopisy, sborníky. Praha : Academia, 2018, pp. 256-257.

6 All of the editions of this fanzine from 1984 to today are in digitized format at http://interkom.vecnost.cz.

7 KUDLÁČ 2017, p. 96.

8 For more on these umbrella organizations: ADAMOVIČ, Ivan. V šedézóně sci-fi. In HROCH, Miloš (ed.) Křičím: „To jsemjá“: Př́iběhy českého fanzinu od 80. let po současnost. Praha : Page Five, 2017, pp. 114-115, 125. 
be described as "distinctive individuals subscribing to a subculture", people who identify with the norms and values of the subculture, but who at the same time emphasise their own personal opinions and attitudes. New "neofans" are constantly entering fandom as part of generational changes, and they are then used as recruits for Fandom as well as new "wild fans".

The aforementioned structure of Czechoslovak fandom emerged as the result of extensive social changes in 1989. The Syndicate of Fantastic Literature Authors was established in December 1989 in an attempt to create a specific writers' organisation, though nothing developed from it. In 1990 the Association of Fans of Science Fiction was formed, which still acted within the spirit of the communist "social organisations" (i.e. official state-controlled organisations), though it rapidly changed into a publication and distribution company and precursor of the "professionalisation" of fantastic literature. A spring meeting of SF clubs in Opava in early May 1990 witnessed the establishment of an official organisation covering local SF clubs, called Czechoslovak SF fandom, which was defined as an "independent legal entity". ${ }^{10}$ Following the breakup of Czechoslovakia in 1993, Fandom was formally divided into Czechoslovak fandom in the Czech Republic, and Czechoslovak fandom in the Slovak Republic, but in reality the subculture of fans has continued as Czech-Slovak, and every member of Fandom is automatically a member of both national organisations. Fandom exists to this day as a civic association. ${ }^{11}$

In addition to creating official organisational structures, gradual professionalisation was a feature of the local subculture of fans in the 1990s. Nearly all of the professional publishers which focused more or less exclusively on fantastic literature arose as a result of the activities of fans who were involved in fandom before 1989. Similarly, the originally amateur distribution of fanzines became the spawning ground for the publication of professional periodicals, though at the same time a certain level of "unprofessionalism" has been maintained in fanzine production.

\section{SF Fanzines Past and Present}

As has been mentioned, the publication of fanzines - amateur magazines produced by fans themselves - has been part of SF fandom from the very start. ${ }^{12}$ The first such fanzine to be produced in Czechoslovakia was Vega, which has been published in Plzeň since 1977, i.e. before fandom became established. Vega was connected to the tramping subculture and was a supplement of the Daily Dudlay magazine from

\footnotetext{
9 KUDLÁČ 2016, pp. 97-98.

10 Stanovy Československého fandomu v ČR, s.z. In ČS Fandom, 2020, https://fandom.cz/index.php/ statuty/5-stanovy-ceskoslovenskeho-fandomu-v-cr-z-s.

11 KUDLÁČ 2016, p. 99.

12 The first fanzines labelled in this way are connected with the start of SF fandom in the USA, see CLUTE, John - NICHOLLS, Peter. The Multimedia Encyclopaedia of Science Fiction. Danbury, CT : Grolier, 1995, pp. 777-779. For more information on SF fanzine in the USA and elsewhere, see e.g. WERTHAM, Fredric. The World of Fanzines. A Special Form of Communication. Carbondale : Southern Illinois University Press, 1973.
} 
the Dudlaj tramping settlement. ${ }^{13}$ Ivan Adamovič considers the first truly Czech SF fanzine to be Sci-fi věstník (Sci-Fi Bulletin), which has been published in Teplice since $1981 .^{14}$

In Czechoslovakia, fanzines were almost exclusively linked to the individual SF clubs which formed the subculture's organisational units; the "personalzines" that were typical of Western SF fandom were rarely found in Czechoslovakia. ${ }^{15}$ From a technical perspective these were periodicals with small print runs (from dozens to hundreds of copies), which often came out irregularly and were copied using the technology available to amateurs (cyclostyle, ormig, occasionally offset, later Xerox). Fanzines contained various reports about club activities, book reviews, opinions, interviews and original as well as translated short stories. As there were no official periodicals, these created the basic communication network for the subculture, which was independent of the official culture, while at the same time it also trained a whole generation of artists who would later become professionals. Jaroslav Olša, Jr., who at the end of the 1980s compiled an extensive bibliography of Czech and Slovak SF fanzines, ${ }^{16}$ wrote in an overview study originally published in the magazine Nemesis $(11-12 / 1996,1 / 1997)$ that by 1990 approximately 60 fanzines with a total of around 400 individual issues had been published. ${ }^{17}$ (Zdeněk Rampas adds the claim that "in my inventory, there are over 550 published issues of periodical fanzines and one-off »book publications" by 1989"). ${ }^{18}$ There is extensive material available for researchers at the website of the collector Karel Dvořák (http://fanziny.4fan.cz), containing digitised content from some of the SF fanzines as well as a list of them.

When summing up the characteristics of Czech SF fanzines in a contemporary encyclopaedia on national samizdat writings, Zdeněk Rampas wrote that Czechoslovak fans, at least in some cases, published "authentic samizdats" whose content may have been "against the regime". According to him, the perceived lack of popular literature and the absence of officially published specialist magazines led to the creation of fanzines, which in itself became a "political act". At the same time, he acknowledges that the regime might deliberately have refrained from applying greater pressure here in order to "allow young people to ventilate their creative energy". Nevertheless, it was never completely free from the risk of punishment. ${ }^{19}$ In the introduction to the same publication, Michal Přibán states that SF fandom in the 1980s had acquired the status of an "unreliable, though on the whole tolerated part of literary life." Although fantastic literature was also published

13 RAMPAS, Zdeněk. SF fanziny. In PŘIBÁŇ, Michal (ed.) Český literární samizdat 1949 - 1989: Edice, časopisy, sborníky. Praha : Academia, 2018, pp. 436-437.

14 ADAMOVIČ 2017, p. 112.

15 ADAMOVIČ 2017, p. 113.

16 OLŠA, Jr., Jaroslav. Bibliografie českých a slovenských fanzinů do roku 1987. Praha : ÚKDŽ, 1988; OLŠA, Jr., Jaroslav. Bibliografie českých a slovenských fanzinů za rok 1988. Praha : ÚKDŽ, 1990.

17 OLŠA, Jr., Jaroslav. Fanziny před listopadem 89. Vývoj a typy science fiction samizdatu. In Fanziny, 2019, http://fanziny.4fan.cz/fanziny.php? $\mathrm{x}=0 \& \mathrm{y}=5 \& \mathrm{z}=0$

18 Email from Zdeněk Rampas to the author on 27 June 2014.

19 RAMPAS 2018, p. 436. 
officially, much of it was still outside the direct control of state power organs. ${ }^{20}$ I believe that these fandom publishing activities fall into a kind of "grey zone"21 or "tolerated culture" (Přibáň also writes about a "samizdat with a stamp"22), whose creators appeared from the outside to be loyal, but internally they certainly were not. ${ }^{23}$ Therefore, members of this subculture cannot be considered to be warriors against the regime. Other subcultures at the time operated in a similar manner; for example, in the 1980s, computer fans expanded their activities to include the publication of fanzines solely as part of Svazarm; thus, "they were not in direct opposition to the regime, though neither were they supporting it."24

From a terminological perspective, as was mentioned in the introduction, the borders between the concept of "samizdat" and "fanzine" are somewhat unclear, though current research clearly understands fanzines as one of several forms of samizdat, linking today's study of subcultures with research into contemporary social history. This definition seems to be more than adequate.

After the turning point of 1989 , attempts were made to create professional magazines focused on fantastic literature either by transforming existing fanzines (the best example here is the first professional SF magazine Ikarie, based on the fanzine Ikarie $X B)^{25}$ or by establishing an entirely new periodical. ${ }^{26}$ Some fanzine distributors set up their own professional publishing houses and often named them after the original periodicals (e.g. Laser, ${ }^{27}$ Leonardo $^{28}$ and Poutník $[\text { Pilgrim }]^{29}$ ). Those traditional printed fanzines which did not want to go down the professional road experienced a temporary decline, but they began to grow again after 1991 with a new generation of fans and a wide spectrum of interests (games and films in addition to literature). Interkom, which continued to be seen as the "main fanzine" of Fandom, has regularly published overviews of fanzines. It is clear from these that the situation is gradually changing and the number and lifespan of printed fanzines has once again been falling since the start of the $21^{\text {st }}$ century, with the latest data of this kind appearing in Interkom in 2004. ${ }^{30}$ In some isolated cases, fanzines which disappeared in 1989 have been resurrected

20 Pर̌IBÁŇ, Michal. Poznámky pro čtenáře a uživatele. In PŘIBÁŇ, Michal (ed.) Český literární samizdat 1949 - 1989: Edice, časopisy, sborníky. Praha : Academia, 2018, p. 90.

21 PŘIBÁŇ, Michal. K dějinám českého literárního samizdatu. In PŘIBÁŇ, Michal (ed.) Český literární samizdat 1949 - 1989: Edice, časopisy, sborníky. Praha : Academia, 2018, p. 41.

22 PŘIBÁŇ 2018, K dějinám, pp. 37-39.

23 This is viewed similarly by ADAMOVIČ 2017, pp. 122-123.

24 ŠVELCH, Jaroslav. První kroky ve strojovém kódu. In HROCH, Miloš (ed.) Křičím: „To jsemjá“: Příběhy českého fanzinu od 80. let po současnost. Praha : Page Five, 2017, p. 64.

25 RAMPAS, Zdeněk - OLŠA, Jr., Jaroslav. Ikarie XB. In P̌̌IBÁŇ, Michal (ed.) Český literární samizdat 1949 1989: Edice, časopisy, sborníky. Praha : Academia, 2018, pp. 251-253.

26 As a result of the division of Czechoslovakia in the 1993 the text will be exclusively about Czech SF fanzines. 27 RAMPAS, Zdeněk - OLŠA, Jr., Jaroslav. Laser. In PŘIBÁŇ, Michal (ed.) Český literární samizdat 1949 - 1989: Edice, časopisy, sborníky. Praha : Academia, 2018, pp. 298-299.

28 RAMPAS, Zdeněk - OLŠA, Jr., Jaroslav. Leonardo. In PŘIBÁŇ, Michal (ed.) Český literární samizdat 1949 1989: Edice, časopisy, sborníky. Praha : Academia, 2018, pp. 304-305.

29 RAMPAS, Zdeněk - OLŠA, Jr., Jaroslav. Poutník. In PŘIBÁŇ, Michal (ed.) Český literární samizdat 1949 1989: Edice, časopisy, sborníky. Praha : Academia, 2018, pp. 379-381.

30 A similar trend at this time also apparently affected the fanzines of other subcultures, for example, fans of heavy metal, see PALÁK, Viktor. Kronikář z bažin. In HROCH, Miloš (ed.) Křičím: „To jsemjá“: Příběhy českého fanzinu od 80. let po současnost. Praha : Page Five, 2017, p. 43. 
(Andromeda News, which came out again from 1992 - 2002),,13 or the periodical continued to be published irregularly, maintaining a specific function (literary-competition annuals) regardless of the changes in the situation at the time (Ko$\check{c}$ as, which has been publishing the winning prose of the Karel Čapek Award since 1982). ${ }^{32}$ The only traditional SF fanzine I know of that has maintained the spirit of the original fanzines from the era of late socialism and been published uninterruptedly (if we do not include Interkom) is the fanzine Světelné roky (Light Years). It has been published by the Čáp husband and wife team since 1983 and focuses mainly on SF films. ${ }^{33}$

The first fanzine on the Internet (Amber Zine) appeared in the mid-1990s, but it was not until the turn of the millennium that fanzine communication began to expand into cyberspace. The original printed fanzines were gradually complemented and finally replaced by e-zines. One of the first was Sarden, which has been published since 2000 as part of the first Czech online newspaper, Neviditelný pes (Invisible Dog), and was organised by Fandom representatives from the generation of fans.

Here it is necessary to point out that e-zines differ from the other digital communication forums that gradually began to fill Czech media at the turn of the millennium. These include blogs, whose structure of dated records arranged chronologically from the most recent to the oldest has the character of a diary, making it more of a personalised medium..$^{34}$ Meanwhile, literary forums are open clubs which discuss amateur works of literature. ${ }^{35}$ Contrastingly, e-zines are much more similar to traditional magazines, and as they are firmly anchored in their respective subcultures, they can be seen as the direct successors to printed fanzines, which is indeed how the majority of fans view them. ${ }^{36}$

The first two decades of the $21^{\text {st }}$ century saw the emergence of several Czech e-zines focusing on fantastic literature, which gradually began to differentiate both in terms of themes and structure. For example, the development of Mfantasy (https://www.mfantasy.cz/) has been very haphazard. It was originally established in 2004 as a literary forum and thus contained only amateur short stories. In 2006 - 2007, and then again since 2012, its creators also published in parallel a type of electronic anthology ("e-magazines"), summarising most of the quarterly content of the e-zine, with the original intention of announcing literary competitions and organising an online authors' workshop. Around 2009 the periodical's structure changed to a magazine format with regular columns (reports, reviews,

31 RAMPAS, Zdeněk - OLŠA, Jr., Jaroslav. Andromeda News. In PŘIBÁŇ, Michal (ed.) Český literární samizdat 1949 - 1989: Edice, časopisy, sborníky. Praha : Academia, 2018, p. 108.

32 RAMPAS, Zdeněk - OLŠA, Jr., Jaroslav. Kočas. In PŘIBÁŇ, Michal (ed.) Český literární samizdat 1949 - 1989. Edice, časopisy, sborníky. Praha : Academia, 2018, pp. 280-281.

33 RAMPAS, Zdeněk - OLŠA, Jr., Jaroslav. Světelné roky. In PŘIBÁŇ, Michal (ed.) Český literární samizdat 1949 - 1989: Edice, časopisy, sborníky. Praha : Academia, 2018, p. 480.

34 PIORECKÝ, Karel. Česká literatura a nová média. Praha : Academia, 2016, pp. 87-135.

35 PIORECKÝ 2016, pp. 137-178.

36 I. Adamovič states that fans' web projects no longer have the character of fanzines and "can be seen more as websites", see ADAMOVIČ 2017, p. 122. 
excerpts from books, interviews). In 2006, one fan cult (the Twilight series of novels by Stephenie Meyer) developed into thee-zine Détinoci (Children of the Night): http://deti-noci.cz/. At the start it had the structure of a magazine and later expanded in scope to include the wider area of fantastic literature. Howard (http:// www.howardhorror.cz/) was established in 2012 and focuses exclusively on horror, again with the structure of a magazine, though it comes out in the form of an e-book that is free to download. Vlčí bouda (Wolf's Hole) (http://vlcibouda.net/) and Dagon have been published since 2013 based on the format of the aforementioned Sarden, i.e. as online magazines focusing on fantasy in the broad media sense (literature, film, comics, games). In May 2018, Dagon (organised by some of the editors of Mfantasy) announced that it would only continue as a periodical on Facebook.

Therefore, the development of Czech SF fanzines went through two phases after 1989. In the 1990s, fanzines (most of them still printed) quickly gave up their pre-revolution role and were replaced by professional periodicals which basically operated the same way as abroad - they mainly provided information about clubs, and their influence spread only to a limited circle of fans. In the new millennium there were changes in the technology for producing and distributing fanzines, which also resulted in a certain change in understanding their function. The virtual format allowed readers to respond almost instantly to a published text, and at the same time the creators could continuously make updates. The external graphic design of e-zines, particularly in the new millennium, also often tried to imitate the level of professionally published periodicals, from which they sometimes took material and in some cases cooperated with in various ways in the media. Naturally, some recent Internet discussions amongst fans have revealed a nostalgia for printed fanzines, which they say contained better quality material and, most importantly, were not subservient to the "commercial influences" of today's media. ${ }^{37}$

\section{"Professionalism" and "Amateurism", Commodification and Subcultural Values, High and Low}

The issue of the relationship between a subculture and the rules of the free market is undoubtedly something that significantly influences the communication of the members of these communities. In his classic work Subculture. The Meaning of Style, Dick Hebdige describes how supposedly each subculture (looking specifically at punk) goes through a cycle of initial resistance to the majority culture before later merging with it. He mentions two forms of a subculture's integration: as a commodity, where the subculture style becomes part of fashion, and ideological, where the members of the subculture adapt to the norms of the hegemonic culture. Naturally, he acknowledges that it is very difficult to establish a clear line between commercialism and a subculture's originality. ${ }^{38}$

37 VANÍČEK, Lukáš. Fanzine is not dead. In FantasyPlanet, 27. March 2012, https://www.fantasyplanet.cz/ za-obzorem/redakcni-uvodniky/fanzin-is-not-dead/.

38 HEBDIGE, Dick. Subculture: The Meaning of Style. London : Routledge, 1979. 
If we look at the development of fandom media in light of the above-mentioned discussions, it is impossible to overlook the fact that certain types of "commodification" occur here. Naturally, this depends on the media format and its range of technological and communication possibilities. In terms of printed periodicals, their production costs and means of distribution, it is understandable that market rules had to apply from the start, while the periodicals remained focused on the fandom public. The first professional Czech magazine focused on fantastic literature, the monthly Ikarie, continued the fanzine tradition when it was established in 1990, while others (Ramax, Nemesis, Pevnost [Fortress]) mainly came into existence as part of the media industry. ${ }^{39}$ Interkom had a special position among printed periodicals - a fanzine in terms of its "spirit" and distribution, i.e. an unambiguously subcultural product, which at the same time is presented within fandom as parallel to professional magazines (e.g. with its inclusion in the category of Best Magazine by the Academy of Science Fiction, Fantasy and Horror, which otherwise includes only professional publications), in other words as a "semiprozine". 40

A slightly different situation occurred in the virtual sphere between e-zines. The gradual movement of fanzines to their Internet form created an area which fans thought was suitable for their creative activities, while at the same time being free of significant commercial pressures for several years. At the end of the period under investigation this situation began to change, and some e-zines became part of a publishing house or other media projects.

There are two subcultural online periodicals which can serve as general examples. Sarden, established in 2000 as part of Ondřej Neff's Internet newspaper Neviditelný pes, is today still a fans' project and to a certain degree independent of the commercial media. Fantasy Planet, which was set up in the same year as part of fans' activities, was bought in 2008 by the publisher Fantom Print, which came out of the fandom environment and which basically retained the original form of the website (perhaps because it also had its own e-shop). While these Internet magazines still maintain contact with the subculture from which they emerged, the increased interest in fantastic literature in the cultural industry has also encouraged the emergence of Internet periodicals, which from the outset have been commercially focused exclusively, targeting young people in particular. This was the way in which, for example, the fantastic-literature website Fanzine was incorporated in 2009 into Topzine.cz, which systematically covers the different areas of interest of today's youth, moving beyond distinctive subcultures. There are, therefore, two basic elements in the conflict between the "professional" and "amateur" approach to fantastic literature. One of them involves fans being against the elite culture from the position of a specific type of cultural production, which from their viewpoint represents a parallel to "high" culture while maintaining the subculture's originality and emphasis on sharing common values which 
need not be identified with mainstream values. The second element is fans' active connection with the mass cultural industry, which does not negate the legitimacy of their own distinctive creativity and, conversely, often enriches popular products in an interesting way. The tension between these two elements brings dynamism to SF fandom and gives it the partial character of post-subcultural communities, which are more depoliticised and hedonistic, with unclear boundaries. ${ }^{41}$ As today shows, from this perspective the community of fantastic-literature lovers is nothing exceptional - for example, since around 2000 the Czech subculture of comics fans has veered between an artistic, almost experimental concept of comics, to viewing them as "trivial entertainment" ${ }^{42}$ It is no coincidence that these two subcultures overlap to a large degree.

\section{Conclusion: Are All Subcultures (Necessarily) Political? ${ }^{43}$}

From my findings it appears that since it was part of the unofficial culture of late socialism (see above), Czech/Slovak SF fandom has been apolitical, or in other words, it has not adopted any distinctive critical social positions. Even in today's world of social activism and calls for popular culture, including fantastic literature, to be "more engaged", it remains the case that this community stands apart from ideologies, including political ideologies. For lovers of fantastic literature, the genre itself in the form of literature/film/games is what is important, and they avoid using this medium as a tool for social criticism or direct subversion. Their own opinions and attitudes are coded in the way they communicate with each other, and thus they do not openly declare for a particular idea in the public realm.

In his aforementioned book, Miloš Hroch writes that, on the one hand, the publication of fanzines prior to 1989 was inspired by the local samizdat publications, and on the other, they tried to resemble the unattainable West. To differing degrees their creators found themselves between the "grey zone" and open encounters with the regime. ${ }^{44} \mathrm{He}$ also states that fanzines today are "still the incubators of new artistic trends and detonators of social revolutions. ${ }^{\prime 45}$ Naturally, since the 1980s Czech fans of fantastic literature have not experienced such dramatic developments - their world has long been the world of a ghetto, where they amuse themselves with pop-culture artefacts, albeit transforming them in their own way and sharing these activities, though today mainly in the virtual world. ${ }^{46}$

41 MUGGLETON, David. Inside Subculture. The Postmodern Meaning of Style. Oxford; New York : Berg, 2000. 42 TESAŘ, Antonín. Nikdy nebudeme normální. In HROCH, Miloš (ed.) Křičím: „To jsemjá“: Příběhy českého fanzinu od 80. let po současnost. Praha : Page Five, 2017, p. 177.

43 In recent years Czech research into subcultures has emphasized social conflict and/or the political aspects of subcultural activities, see e.g. DANIEL, Ondřej. Násilím proti „novému biedermeieru“. Subkultury a většinová společnost pozdního státního socialismu a postsocialismu. Př́íbram : Pistorius a Olšanská, 2016; DANIEL, Ondřej (ed.) Kultura svépomocí. Ekonomické a politické rozměry v českém subkulturním prostředí pozdního státního socialismu a postsocialismu. Praha : Filozofická fakulta Univerzity Karlovy, 2016; SLAČÁLEK, Ondřej - CHARVÁT, Jan. Setkávání na okrajových scénách. Průsečíky politického a subkulturního radikalismu v polistopadovém Česku. In Český lid, 2019, Vol. 106, No. 1, pp. 107-126.

44 HROCH 2017, Zkoušel, pp. 27-32.

45 HROCH 2017, Zkoušel, p. 35.

46 Whereas the more radical subcultures are returning to the "DIY" form of printed fanzines as a way of rebelling against the "mainstream" or simply for a feeling of greater authenticity. (see HROCH, Miloš. Zprávy z první linie. Proměny hardcore-punkových fanzinů v postdigitální době. In Český lid, 2019, Vol. 106, 
The research which exists into the attitudes and opinions of Czech SF fans is based mainly on an analysis of their personal statements and shows that their ideas about the social and political situation are not particularly remarkable. ${ }^{47}$

Some subcultures, such as punk and radical feminism, are by their very nature critical of society, and their existence is clearly conditioned by that. Many communities, however, are significantly heterogeneous in their opinions, and their attitudes towards the majority of society vary, and the socio-cultural "centre" and "periphery" often rapidly swap positions. ${ }^{48}$

Therefore, not all subcultures have to be rebellious or "counter-cultural" in character, even though their members certainly do not exist in a "vacuum". In a certain way their activities have always reflected the socio-political situation of the time, most strikingly so under totalitarian regimes (e.g. the tramping ${ }^{49}$ or swing youth ${ }^{50}$ ).

Translation: Graeme Dibble

No. 1, pp. 29-47). With their fondness for e-zines, which are structurally similar to "official" magazines, SF fans are perhaps subconsciously demonstrating a close relationship to the industry of mass culture.

47 KUDLÁČ 2016, pp. 105-111.

48 See most recently CHARVÁT, Jan - KUŘÍK, Bob. Mikrofon je naše bomba: Politika a hudební subkultury mládeže v postsocialistickém Česku. Praha : Togga, 2018.

49 KRŠKO, Jan et al. Český tramping v časech formování a rozmachu. Praha : Academia, 2019.

50 KOURA, Petr. Swingaři a potápky v protektorátní noci: Česká swingo vámládež a její hořkej svět. Praha : Academia, 2016.

Cituj:

KUDLÁČ, Antonín K. K.. Czech Sci-fi Fanzines in the Era of Late Socialism and Early Post-socialism. In Forum Historiae, 2020, Vol. 14, No. 1, s. 18-38. ISSN 1337-6861. DOI: https://doi.org/10.31577/ forhist.2020.14.1.3

PhDr. Antonín Kudláč, PhD

Katedra literární kultury a slavistiky

Fakulta filozofická Univerzity Pardubice

Studentská 95

53210 Pardubice, Česká republika

E-mail: antonin.kudlac@upce.cz 